\title{
Medicinal Plants from Brazilian Cerrado: Antioxidant and Anticancer Potential and Protection against Chemotherapy Toxicity
}

\author{
José Tarcísio de Giffoni de Carvalho (D), Débora da Silva Baldivia, Daniel Ferreira Leite, \\ Laura Costa Alves de Araújo, Priscilla Pereira de Toledo Espindola, Katia Avila Antunes (D), \\ Paola Santos Rocha $\left(\mathbb{D}\right.$, Kely de Picoli Souza $\mathbb{D}^{\text {, }}$, and Edson Lucas dos Santos
}

Research Group on Biotechnology and Bioprospecting Applied to Metabolism, Federal University of Grande Dourados, Dourados, Brazil

Correspondence should be addressed to Edson Lucas dos Santos; edsonsantosphd@gmail.com

Received 8 March 2019; Revised 16 June 2019; Accepted 15 July 2019; Published 25 August 2019

Guest Editor: Patrícia Rijo

Copyright ( 2019 José Tarcísio de Giffoni de Carvalho et al. This is an open access article distributed under the Creative Commons Attribution License, which permits unrestricted use, distribution, and reproduction in any medium, provided the original work is properly cited.

\begin{abstract}
The use of natural antioxidants in cancer therapy has increased: first, due to the potential of natural antioxidants to kill tumour cells and second, because of their capacity to protect healthy cells from the damage caused by chemotherapy. This review article discusses the antioxidant properties of extracts obtained from medicinal plants from the Brazilian Cerrado and the cell death profile induced by each of these extracts in malignant cells. Next, we describe the capacity of other medicinal plants from the Cerrado to protect against chemotherapy-induced cell toxicity. Finally, we focus on recent insights into the cell death profile induced by extracts from Cerrado plants and perspectives for future therapeutic approaches.
\end{abstract}

\section{Introduction}

Natural products or their derivatives represent approximately $60 \%$ of all chemotherapeutic agents approved by the Food and Drug Administration (FDA), including vincristine, vinblastine, and Taxol [1-3]. However, the search for medicinal plants with anticancer properties has intensified in recent years since chemotherapeutic agents are limited by a high rate of drug resistance and by severe side effects. Additionally, some of the current drugs used in cancer therapy are very expensive to produce $[2,4]$. Therefore, there is great interest in the discovery and identification of effective anticancer compounds and molecules with low production costs and high target cell selectivity [5-7].

Brazil is considered to be the territory with the richest biodiversity in the world [8-11]; the Cerrado is the second main biome, exhibiting a great diversity of natural plants $[9,12,13]$. The Cerrado is located in the middle west of Brazil, encompassing almost 2 million $\mathrm{km}^{2}$ that covers $21 \%$ of the Brazilian territory $[14,15]$.

Numerous studies have evaluated the biological effects of extracts from medicinal plants from the Cerrado. These extracts include Stryphnodendron adstringens, popularly known as barbatimão, which has displayed antiulcerogenic and antifungal effects [16], and Campomanesia adamantium, popularly known as Guavira, which has presented antidiabetic properties, anti-inflammatory, and diuretic actions [17]. Another plant from the Brazilian Cerrado is Senna velutina; little is known about its biological effects, but an important study investigated its antitumour activity in a leukaemia cell lineage [18]. In addition, the Jacaranda [19] and Harconia [20] genera are other examples of medicinal plants from the Cerrado commonly used in folk 
medicine and with some described biological properties, mainly antioxidant activity. Finally, Schinus terebinthifolius and Guazuma ulmifolia are used in traditional medicine to treat ulcers, diarrhoea, arthritis, and infections [21] and inflammation, gastrointestinal diseases, and diabetes [22], respectively. The botanical features and geographical distribution of plants from the Brazilian Cerrado are outlined in Table 1.

This review article discusses the antioxidant properties of extracts obtained from medicinal plants from the Brazilian Cerrado and the cell death profile induced by these extracts in malignant cells. Next, we describe the capacity of other medicinal plants from the Cerrado to protect against chemotherapy-induced cell toxicity.

\section{Redox Balance Potential}

Natural antioxidants are molecules that protect cells from the damage induced by reactive oxidative species (ROS) $[4,66]$. These $\mathrm{ROS}$, including superoxide anion $\left(\mathrm{O}_{2}{ }^{-}\right)$ and hydrogen peroxide $\left(\mathrm{H}_{2} \mathrm{O}_{2}\right)$, are involved in various cellular processes (host immune defence, cell signaling, cellular respiration process, and others); however, if they are not properly regulated by the antioxidant system, ROS initiate a number of deleterious effects, which may cause the oxidation of biomolecules [67, 68]. For example, excessive ROS results in lipid peroxidation, a process in which free radicals attack polyunsaturated fatty acids, a lipid present in the cell membrane, resulting in membrane rupture and the production of toxic molecules, especially malondialdehyde (MDA), associated with cell damage and mutagenicity [68-70].

Superoxide is generated from diverse metabolic pathways in cells, including the mitochondrial respiratory chain and the enzymatic action of cytochrome p450 and NADPH oxidases $[71,72]$. The superoxide that results from these reactions can undergo dismutation to generate water $\left(\mathrm{H}_{2} \mathrm{O}\right)$ by superoxide dismutase (SOD), an enzyme in the antioxidant system or can react with nitric oxide $\left(\mathrm{NO}^{*}\right)$, to generate reactive nitrogen species, such as peroxynitrite $\left(\mathrm{ONOO}^{-}\right)$, the most powerful oxidant $[67,69]$.

Superoxide dismutase catalyses the dismutation of $\mathrm{O}_{2}{ }^{--}$ to hydrogen peroxide $\left(\mathrm{H}_{2} \mathrm{O}_{2}\right)$, which is a less reactive species and a substrate for other enzymes involved in the antioxidant system. Successively, in a Fenton reaction, $\mathrm{H}_{2} \mathrm{O}_{2}$ can be modified to a toxic hydroxyl radical $\left(\mathrm{OH}^{-}\right)$in the presence of transmission metals, such as iron $\left(\mathrm{Fe}^{2+}\right)$, and therefore should be decomposed to $\mathrm{H}_{2} \mathrm{O}$. For this step, the most efficient enzymatic antioxidants are catalase (CAT) and/or glutathione peroxidase enzymes (GPx) [73, 74]. GPx reduce peroxides to water (or alcohol) through oxidation of selenol residue to selenenic acid (RSe-OH) groups which are converted back to selenols by the tripeptide glutathione (GSH). Oxidazed gluthatione (GSSH) is oxidazed back to GSH by glutatione reductase $[67,69,73]$.

Numerous studies have evaluated the antioxidant potential of extracts from plants from the Cerrado. Campos et al. [18] studied the effects of S. velutina on radical scavenging activity. Extracts prepared from the leaves of S. velutina in an ethanol solvent were found to be very potent inhibitors of radical scavenging activity by the DPPH $\left(2,2^{\prime}\right.$-diphenyl1-picrylhydrazyl) method, and the concentration necessary for the $50 \%$ inhibition $\left(\mathrm{IC}_{50}\right)$ of $\mathrm{DPPH}$ of these extracts was lower than that of the commercial antioxidant butylated hydroxytoluene (BHT) $(6.3 \pm 1.3$ versus $21.3 \pm 1.2 \mu \mathrm{g}$ $/ \mathrm{mL}$ ). Similarly, Dos Santos et al. [46] evaluated the antioxidant capacity of a leaf extract of Hancornia speciosa in an ethanolic solvent and also observed a potential activity by the DPPH method and improved $\mathrm{IC}_{50}$ values in relation to BHT $(9.4 \pm 0.8$ versus $66.1 \pm 23.6 \mu \mathrm{g} / \mathrm{mL})$.

Espindola et al. [38] found that an extract prepared from the root of $C$. adamantium in an aqueous solvent and BHT had similar antioxidant capacities by the DPPH method $\left(\mathrm{IC}_{50}: 37.3 \pm 4.1\right.$ versus $\left.36.1 \pm 9.1 \mu \mathrm{g} / \mathrm{mL}\right)$ [38]. Baldivia et al. [16] evaluated the antioxidant effects of an extract from the stem bark of $S$. adstringens by the DPPH and ABTS methods (2,2' -azino-bis(3-ethylbenzothiazoline-6-sulfonic acid)). The antioxidant efficacy of $S$. adstringens is similar to that of ascorbic acid according to both methods (DPPH $\mathrm{IC}_{50}, 3.81 \pm 0.02$ versus $2.65 \pm 0.03 \mu \mathrm{g} / \mathrm{mL}$; ABTS $\mathrm{IC}_{50}, 1.83$ \pm 0.15 versus $1.34 \pm 0.01 \mu \mathrm{g} / \mathrm{mL}$ ).

These results demonstrate that the extracts obtained from S. velutina, H. speciosa, C. adamantium, and S. adstringens may directly react with free radicals by electron donation radical scavenging, thereby inhibiting ROS-induced damage. These actions can be attributed to the presence of phenolic compounds. The antioxidant efficiency of a phenolic compound depends on the capacity of a hydrogen atom in a hydroxyl group on an aromatic structure to be donated to a free radical $[75,76]$. Among the phenolic compounds described as major potential antioxidants, gallic acid is a well-described phenolic compound with antioxidant and antihaemolytic activities in human erythrocytes [77-79]. Procyanidins are also excellent antioxidants capable of protecting erythrocytes from oxidative haemolysis [80, 81]. Furthermore, flavonoids known as catechins [82, 83], rutin $[84,85]$, and quercetin $[86,87]$ are among the most abundant and important chemical constituents of plant species and are described as lipid peroxidation inhibitors. The phenolic compounds identified in extracts of $C$. adamantium, S. velutina, and S. adstringens are listed in Table 2.

The extracts from these plants also showed antioxidant activity and demonstrated lipid peroxidation prevention in $2,2^{\prime}$-azobis(-amidinopropane) dihydrochloride- (AAPH-) induced erythrocyte haemolysis as evidenced by MDA production. Importantly, MDA is related to cell damage and mutagenicity and the inhibition of this process can restore cell homeostasis and prevent the development of oxidative stressrelated disease [88].

Casagrande et al. [19] evaluated the activities of SOD, CAT, and GPx antioxidant enzymes in human erythrocyte lysates and found that a hydroethanolic extract of Jacaranda decurrens subsp. symmetrifoliolata leaves increased the enzyme activity of glutathione peroxidase and reduced the activity of superoxide dismutase and catalase. Rocha et al. [21] showed that the enzymatic activity of SOD and GPx enzymes increased upon treatment of human erythrocytes 


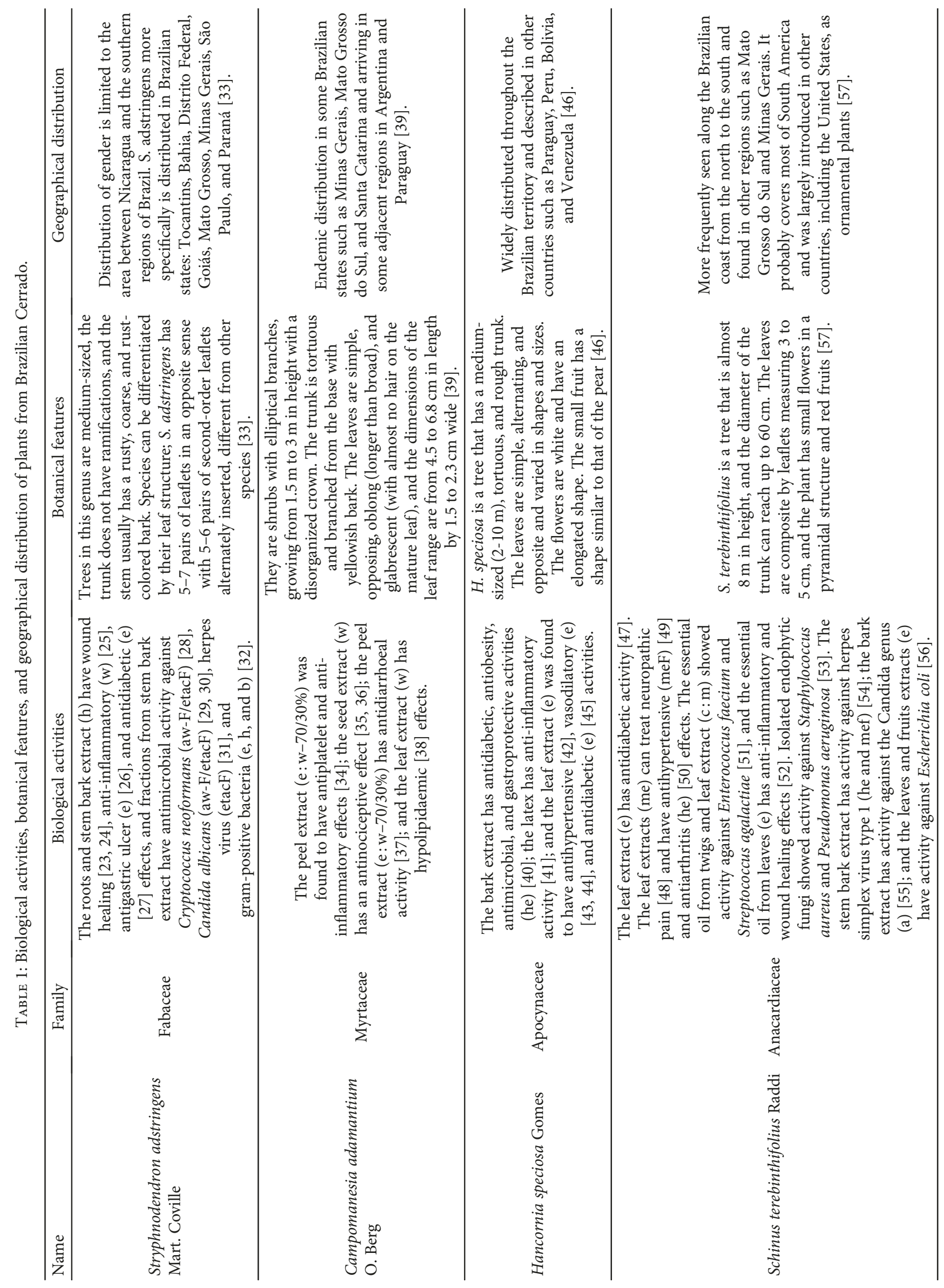




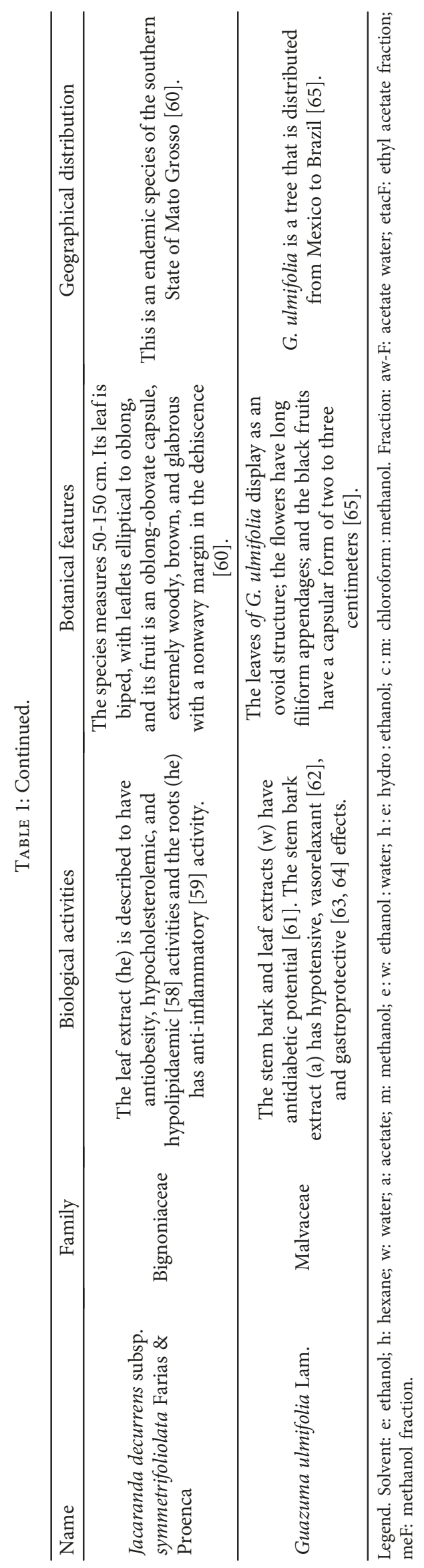




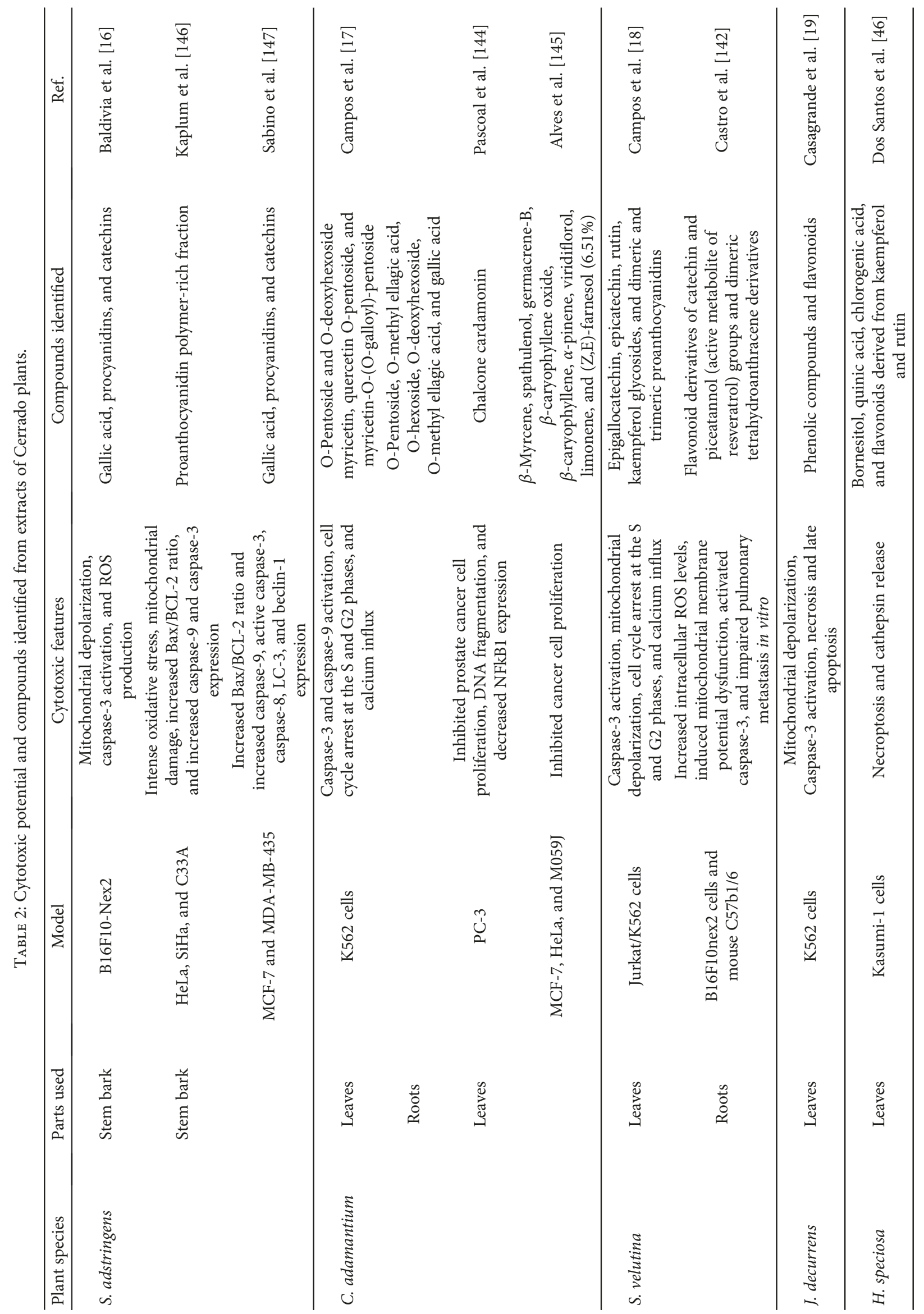




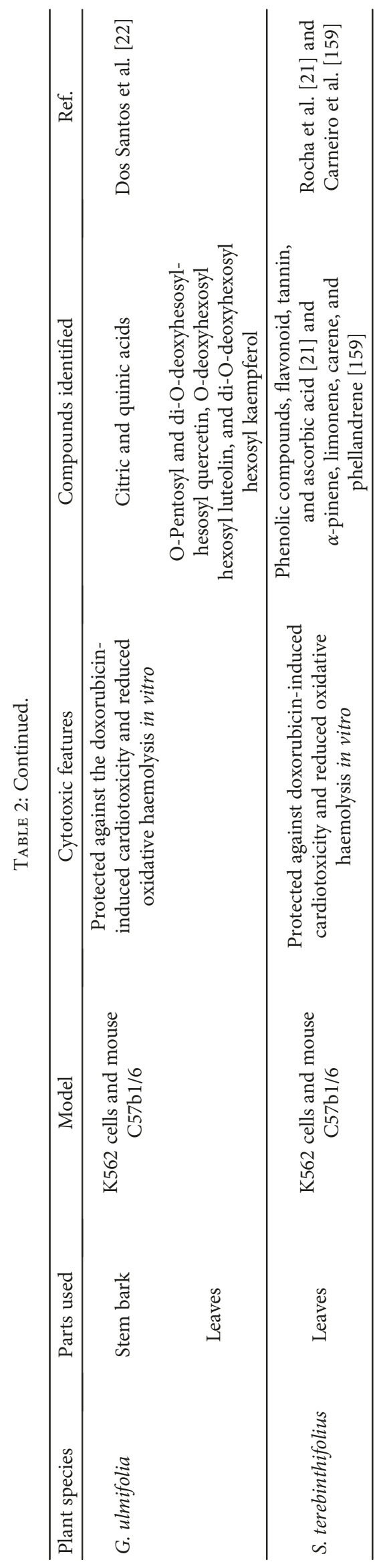


with an extract prepared from the leaves of S. terebinthifolius in methanol solvent. Based on these results, it seems that $J$. decurrens and S. terebinthifolius may modulate the endogenous antioxidant system.

Extracts of $C$. adamantium, in addition to scavenging activity, were described to reduce MDA in vitro and in vivo [38]. The capacity of $C$. adamantium to present in vivo antioxidant effects represents a major advantage for the development of new products. In many cases, in vitro findings are not reproduced in an organism due to various factors, such as enzyme inactivation, poor absorption, and tissue distribution $[89,90]$. This finding suggests that the C. adamantium extract showed a bioavailability profile suitable for use in vivo.

These results demonstrated that these extracts are very potent antioxidants due to their radical scavenging capacity and their capacity to protect the cell against lipid peroxidation. Furthermore, the synthetic antioxidants commonly used are reported to be mutagenic and cause liver injury [91]. The search for new antioxidants that are more effective and have a better toxicity profile than current antioxidants is desirable, and the plants described here may represent interesting targets for this purpose.

\section{Antioxidants and Cancer}

Cancer is a multistage process resulting in an uncontrolled cell cycle and cell division and apoptosis resistance and is one of the main diseases that cause mortality worldwide [92]. Carcinogenesis is a process that involves multiple steps, including an initiation phase that can occur after exposure to a carcinogenic agent, and commonly results in increased production of ROS $[93,94]$. The initialization of cancer cells commonly depends on mutations in genes related to the regulation of the cell cycle, apoptosis, and/or growth factor signalling pathways, which can be induced by ROS-mediated DNA mutations $[95,96]$.

The interaction between antioxidants and cancer cells can occur in at least three ways:

(i) Prevention: the ability of antioxidants to protect cells from ROS-induced DNA damage is the basis of the association of antioxidants with cancer prevention [97-99]

(ii) Protects against chemotherapy toxicity: chemotherapy commonly increases the production of ROS, which induces oxidative stress in cancer cells and other tissues. Excessive ROS may cause a disruption in cellular homeostasis, which can lead to toxicity. Therefore, to improve the clinical response to chemotherapy, combination approaches with antioxidants are being investigated by providing protection against toxic side effects $[100,101]$

(iii) New anticancer molecules: recent evidence has suggested that antioxidants can also be used to eliminate cancer cells. Over the last few decades, antioxidant extracts from medicinal plants have shown a great cytotoxic potential $[102,103]$

\section{Cell Death Pathway in Cancer Cells}

Currently, cell death continues to be considered a complex process that results in a variety of pathways [104-106]. The fact that cells die through different death pathways and that cancer cells can be resistant to each cell death signalling pathway is a relevant aspect in the development of new drugs for anticancer therapy $[107,108]$. To date, knowledge of the cell death pathway induced by medicinal plants from the Cerrado is still scarce $[109,110]$.

4.1. Classical Cell Death. Apoptosis is a regulated and controlled process accompanied by a series of hallmarks, including cell shrinkage, chromatin condensation, DNA fragmentation, and apoptotic body formation, which is dependent on the activation of a protease enzyme family called caspases $[111,112]$. In apoptosis, a change in the membrane of the cell marks the cell for recognition and phagocytosis by macrophages [113, 114].

Despite the modulation of apoptosis by drugs in cancer cells, the activation of the intrinsic pathway is a critical step $[109,115]$. In response to insults, the opening of pores occurs in the mitochondrial membrane and the release of proapoptotic factors, such as cytochrome $c$, then forms an apoptosome complex in the cytosol together with the apoptosis inductor factor and pro-caspase-9, leading to caspase-9 activation. Caspase- 9 then activates effector caspases such as caspase-3, resulting in the cleavage of several cellular targets involved in all aspects of apoptosis. The release of proapoptotic factors from mitochondria is regulated by proapoptotic (BAX) and antiapoptotic (Bcl-2) proteins [116-118].

In addition to the Bcl-2 family, the intrinsic pathway can also be modulated by intracellular calcium [119-121] and the ROS generated by mitochondria [71, 72, 122]. The ROS generated by mitochondria, or elsewhere in the cells, can activate p53, which activates proapoptotic Bcl-2 proteins that can inhibit the functions of antiapoptotic proteins [71, 122-124]. Moreover, ROS cause mitochondrial membrane depolarization and/or open Bax/Bak channels on the mitochondrial membrane, which allows for the release of apoptosis-inducing factor, endonuclease G, cytochrome c, and Smac/Diablo into the cytosol [72, 124]. Furthermore, the perturbation of intracellular $\mathrm{Ca}^{2+}$ homeostasis is also associated with cell death. Endoplasmic reticulum stress responses can induce lesions that affect membrane integrity and the release of $\mathrm{Ca}^{2+}[120,121,125]$. Following $\mathrm{Ca}^{2+}$ efflux into the cytoplasm, the proapoptotic proteins Bak and Bax, which are located in both the reticulum and mitochondria, may be delivered to the cytosol. Calcium overload can induce mitochondrial dysfunction and cell death accompanied by membrane rupture, a process called necrosis $[119,125]$.

4.2. Alternative Cell Death Pathway. For several decades, apoptosis was depicted as programmed cell death in malignant and healthy cells and as a pivotal target for new therapies. Recently, other forms of cell death have also been increasingly noted $[111,126]$. Discovering novel therapeutic strategies that may induce alternative cell death pathways 


$$
\begin{array}{lll}
\text { I: } \text { S. velutina } & \text { III: S. adstringens } & \text { V: J. mimosifolia } \\
\text { II: C. adamantium } & \text { IV: } \text { H. speciosa } &
\end{array}
$$

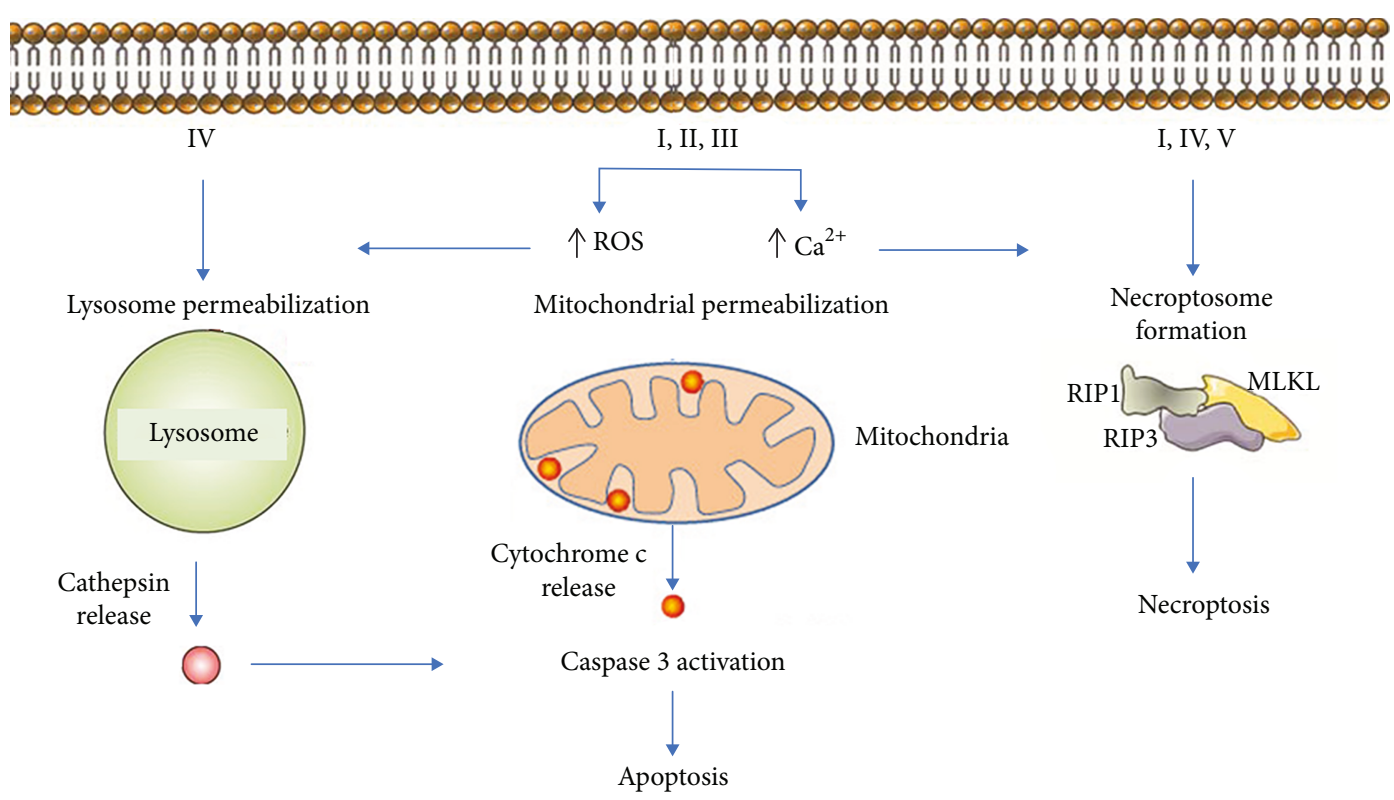

FIgURE 1: Cell death profile induced by extracts and/or compounds from medicinal plants of Cerrado.

appears to be especially useful for opposing malignant cell resistance to caspase-dependent apoptosis [127].

Necroptosis is a form of necrosis that occurs under caspase-deficient conditions $[128,129]$. At the molecular level, necroptosis depends on the activation of serine/threonine receptor-interacting protein kinases 1 and 3 (RIPK1 and RIPK3) by death receptor ligands, which leads to the activation of mixed lineage kinase domain-like pseudokinase (MLKL) [130-132], allowing for a cascade of intracellular events involving $\mathrm{Ca}^{2+}$ influx, ROS production, and membrane rupture [133]. Moreover, accumulating evidence has shown that necroptosis promotes an anticancer immune response [134].

Lysosome-dependent cell death is initiated by perturbations of intracellular homeostasis and is demarcated by the permeabilization of lysosomal membranes [135-137]. Upon lysosomal stress, lysosome-dependent cell death proceeds through membrane permeabilization, resulting in the release of proteolytic enzymes from the cathepsin family to the cytoplasm, which activates death signalling pathways. More commonly, ROS play a prominent causal role in lysosomal permeabilization. The production of hydroxyl radicals by Fenton reactions destabilizes the lysosomal membrane upon lipid peroxidation, but an increase in cytoplasmic $\mathrm{Ca}^{2+}$ is also a key regulator reportedly involved in the activation of lysosomal cell death [138, 139]. Moreover, lysosomal dysregulation may be associated with alterations in autophagy and the role of ROS in homeostasis and cell death [137]. Autophagy is a self-digestive process that involves lysosomal fusion to degrade unnecessary or dysfunctional cellular components [140]. The role of autophagy in cancer is controversial; thus, the modulation of autophagy depends on each subtype of malignant cells and an improved understanding of this pathway in the cancer environment [141].

\section{Cell Death Profile Induced by Plants from the Cerrado}

Several reports from our group [16-19] have demonstrated the potential anticancer properties of medicinal Cerrado plants. Assessing the cell death profile induced by these extracts, through cell death inhibitors and/or caspase detection indicated the involvement of different cell death pathways for each plant extract. For example, many studies have demonstrated the antitumour potential of plant extracts through caspase-independent cell death, including H. speciosa [20] and J. decurrens [19], while others such as C. adamantium [17], S. velutina [18], and S. adstringens [16] killed malignant haematologic cells or melanoma cells through apoptosis (Figure 1 and Table 2).

Campos et al. [18] studied the effect of an extract from the leaves of $S$. velutina in two leukaemia cell lines: Jurkat cells, acute T cell leukaemia cells, and K562, Philadelphia chromosome-positive cells. Jurkat cells were found to be more sensitive to the cytotoxic effect of S. velutina than K562 cells, and this effect was accompanied by caspase- 3 activation, mitochondrial depolarization, and cell cycle arrest at the $\mathrm{S}$ and G2 phases. Furthermore, these features were reversed by chelation of calcium, demonstrating the involvement of calcium as the main regulator of cell death mediated by S. velutina. Castro et al. [142] evaluated the effect of an extract from the roots of $S$. velutina on a melanoma cell line B16F10-Nex2 and also evaluated the antimetastatic effect of this extract using models of tumour volume progression and pulmonary nodule formation in $\mathrm{C} 57 \mathrm{Bl} / 6$ mice. The extract reduced cell viability and promoted apoptotic cell death, caspase- 3 activation, with increased intracellular calcium and ROS levels, and cell cycle arrest at the sub-G0/G1 phase. In vivo, the tumour volume 
progression and pulmonary metastasis of S. velutina-treated mice decreased by over $50 \%$. Taken together, these results show that $S$. velutina had in vitro and in vivo antitumour effects, predominantly through apoptosis, thus demonstrating its promising potential as a therapeutic agent in the treatment of melanoma, leukaemia, and possibly other types of cancer.

Other studies have identified the in vitro antiproliferative activity of the extract from leaves of $C$. adamantium in many cell lineages, including murine melanoma cells (B16-F10) [143], prostate cancer cells (PC-3) [144], breast adenocarcinoma cells (MCF-7), cervical adenocarcinoma cells (HeLa), and glioblastoma cells (M059J) [145]. However, none of these studies evaluated the cell death profile induced by extract of $C$. adamantium. In another study, Campos et al. [17] studied the cell death profile induced in Jurkat cells by an extract prepared from the leaves and roots of C. adamantium. A dose-dependent inhibition of viability occurred in cells incubated with the leaves and roots of C. adamantium. This effect was dependent on the accumulation of cytosolic $\mathrm{Ca}^{2+}$ and on cell cycle arrest at the $S$ phase. In addition, the cell death induced by extracts was likely mediated by the intrinsic apoptotic pathway, since both extracts induced the activation of caspase- 9 and caspase-3, and cell death was reversed after incubation with a general caspase inhibitor.

Baldivia et al. [16] found a similar profile of cell death in a study evaluating the effect of a hydroethanolic extract of the stem bark from $S$. adstringens on the melanoma cell line B16. S. adstringens increased the production of ROS, which may have induced the disruption in mitochondrial membrane potential that caused the apoptotic cell death observed in melanoma cells. These in vitro experiments demonstrated that $S$. adstringens is a potent cytotoxic extract that induces apoptosis-mediated cell death [16]. Kaplum et al. [146] investigated the in vitro anticancer activity of a proanthocyanidin polymer-rich fraction of the stem bark from S. adstringens (extracted in acetone: water) in cervical cancer cell lines, including HeLa (HPV18-positive), SiHa (HPV16-positive), and $\mathrm{C} 33 \mathrm{~A}$ (HPV-negative) cells, and evaluated in vivo anticancer activity. HeLa and $\mathrm{SiHa}$ cells treated with the extract exhibited intense oxidative stress, mitochondrial damage, and increased Bax/BCL-2 ratio and caspase-9 and caspase- 3 expression. The inhibition of ROS production by $\mathrm{N}$-acetylcysteine significantly suppressed oxidative stress in both cell lines. In vivo, the extract significantly reduced tumour volume and weight of Ehrlich solid tumours and significantly increased lipoperoxidation, indicating that it also induced oxidative stress in the in vivo model. These findings indicate that the proanthocyanidin polymer-rich fraction of $S$. adstringens may be a potential chemotherapeutic candidate for cancer treatment. Sabino et al. [147] investigated the in vitro anticancer activity of a fraction isolated from an aqueous leaf extract of $S$. adstringens in breast cancer cell lines. The fraction was cytotoxic against two human breast cancer cell lines: the estrogen receptor-positive cell line MCF-7 and the triple-negative cell line MDA-MB-435. Treatment with the fraction increased the expression of Bax, caspase-9, active caspase-3, caspase-8, LC-3, and beclin-1 and decreased the expression of Bcl-2, caspase-3, and pro-caspase- 8 in cancer cells. Taken together, these results show that $S$. adstringens had in vitro and in vivo antitumour effects, predominantly through apoptosis, thus demonstrating its promising potential as a therapeutic agent in the treatment of melanoma, cervical cancer, breast cancer, and possibly other types of cancer.

Despite the benefits of the pharmacological cancer therapies, the high toxicity of chemotherapeutic drugs is one of the main identified problems. Importantly, in this context, $S$. adstringens and $C$. adamantium show less toxicity against healthy normal cells and peripheral blood mononuclear cells (PBMCs) than tumour cells. In particular, extracts made from the leaves of $C$. adamantium did not change the viability of PBMCs at the evaluated concentrations but exhibited an $\mathrm{IC}_{50}$ of $40 \mu \mathrm{g} / \mathrm{mL}$ in Jurkat cells. Although there was a cytotoxic effect of $S$. adstringens on PBMCs, this effect only occurred at the highest concentration evaluated $(\geq 200 \mu \mathrm{g} / \mathrm{mL})$, which is comparable to the $\mathrm{IC}_{50}(65 \mu \mathrm{g} / \mathrm{mL})$ exhibited against $\mathrm{B} 16$ cells, suggesting a high therapeutic index. These experiments indicate that these plants show selective effects against cancer cells and possibly do not confer any toxicity to healthy normal cells. New targeted therapies with low toxicity and limited side effects are promising for the development of new anticancer agents [148].

Dos Santos et al. [46] evaluated the cell death profile of an extract from $H$. speciosa in an acute myeloid leukaemia cell line, Kasumi-1. The extract from H. speciosa promoted caspase-independent apoptosis because the pancaspase inhibitor did not inhibit the cytotoxic activity of these extracts. This extract killed Kasumi-1 through the involvement of cathepsins and necroptosis and consequently, an alternative pathway of cell death. Cell signalization dependent on lysosomal degradation remains not yet understood, and it seems to modulate autophagic flux [137]. Thus, additional studies evaluating the modulation of autophagic flux mediated by $H$. speciosa are desirable.

Casagrande et al. [19] evaluated the cell death profile induced by extracts from J. decurrens in K562 erythroleukaemia cells. These researchers found concentration-dependent cytotoxic activity against the malignant cells studied, which occurred through late apoptosis and necrosis, the activation of caspase-3, and a decrease in mitochondrial membrane potential. Clinically, this cell death pathway (necrosis and necroptosis) is promising for the development of new anticancer compounds against malignant cells resistant to apoptosis [149, 150]. Moreover, accumulating evidence has shown that necroptosis promotes an anticancer immune response [134]. The great potential of necroptosis induced by $H$. speciosa and $J$. decurrens suggests further evaluation of the immunogenicity capacity of these medicinal plants.

Many phenolic compounds derived from Cerrado plants have demonstrated potential anticancer properties. At high concentrations, the phenolic compounds can act as prooxidants and impair the redox balance of malignant cells [151-155]. Gallic acid is a phenolic compound found in both C. adamantium and S. adstringens. Gallic acid induces death in various cell lines via the intrinsic apoptotic pathway 
[79-81]. S. velutina also has a large number of phenolic compounds; specifically, the phytochemical analysis of roots identified flavonoid-like molecules, such as epigallocatechin, epicatechin, rutin, kaempferol glycosides, and dimeric and trimeric proanthocyanidins [18], and identified the main compounds to be the flavonoid derivatives of catechin and piceatannol (active metabolite of resveratrol) groups and dimeric tetrahydroanthracene derivatives [142].

Accordingly, several flavonoids, such as luteolin, jacaranone, triterpenes, ursolic acid, and oleanolic acid, have been identified in the genus Jacaranda and their cytotoxic activities have been described [155-158]. Further studies to isolate and identify the compounds in the medicinal plants $H$. speciosa, J. decurrens, S. velutina, C. adamantium, and $S$. adstringens and clinical trials to study these extracts and/or isolated compounds have potential to facilitate the development of alternative therapeutic strategies and the design and selection of new drugs for cancer therapy.

\section{Protection against Chemical Toxicity by Plants from the Cerrado}

Chemotherapy commonly increases the production of ROS, which induces oxidative stress in cancer cells and other tissues $[160,161]$. Excessive ROS may disrupt cellular homeostasis, leading to toxicity [162-164]. In fact, after chemotherapy treatment, oncology patients exhibit signs of lipid peroxidation in plasma, reduced levels of antioxidant vitamins in the blood, and decreased levels of GSH in tissues [165]. For example, drugs such as taxanes (paclitaxel and docetaxel) and vinca alkaloids (vincristine and vinblastine) induce cell death by cytochrome $\mathrm{c}$ release from mitochondria and interfering with the electron transport chain, resulting in the production of superoxide radicals [166]. Other drugs, such as anthracyclines (for example, doxorubicin), also generate extremely high ROS levels [167].

Combinatory approaches with antioxidants can protect the health tissues against toxic side effects, improving the clinical response of chemotherapy [164, 168-170]. Regardless of the role of plant antioxidants from the Cerrado in chemotherapy, two recent studies evaluated the effect of doxorubicin on chemotherapy using in vitro and in vivo models. Dos Santos et al. [22] evaluated the capacity of G. ulmifolia extract to protect against doxorubicin injury in vitro and in vivo. The oxidative stress markers in human erythrocytes exposed to doxorubicin, including haemolysis and MDA, were reduced by the combined use of G. ulmifolia extract and doxorubicin. G. ulmifolia extract also induced cardioprotection in rats treated with doxorubicin. G. ulmifolia extract was able to prevent MDA production in the cardiac tissue of animals treated with doxorubicin. Similarly, Rocha et al. [21] described the potential of S. terebinthifolius to protect against doxorubicin injury in vitro and in vivo. The treatment of $\mathrm{C} 57 \mathrm{Bl} / 6$ mice with a $S$. terebinthifolius leaf extract protected against doxorubicin-induced cardiotoxicity, corroborating the results of the reduced oxidative haemolysis in vitro. The cotreatment of doxorubicin with G. ulmifolia or S. terebinthifolius did not attenuate cytotoxicity in erythroleukaemic cells, confirming that these antioxi- dants do not specifically interfere with the cytotoxic efficacy of this anticancer agent. In conclusion, G. ulmifolia and S. terebinthifolius have been found to be capable of protecting against the damage caused by doxorubicin and can offer a therapeutic opportunity for treating cancer.

Other studies have evaluated the antimutagenic potential of some plants from the Cerrado. As discussed previously, carcinogenesis initiation, progression, and promotion are processes related to increased intracellular ROS. Martello et al. [171] described the antimutagenic activities of C. adamantium hydroethanolic extract in Swiss mice treated with cyclophosphamide. When the extract was administered in combination with cyclophosphamide, the micronucleus frequency and apoptosis were reduced. Extract components might affect cyclophosphamide metabolism, which possibly leads to the increased clearance of this chemotherapeutic agent. Thus, caution should be exercised when consuming these extracts, especially when received in combination with other drugs. de Oliveira et al. [172] investigated the capacity of $C$. adamantium fruits to protect HepG2 cells (hepatocytes) from carbon tetrachloride- $\left(\mathrm{CCl}_{4^{-}}\right)$induced toxicity. Carbon tetrachloride $\left(\mathrm{CCl}_{4}\right)$ is a highly toxic chemical that is used to investigate hepatotoxicity. Pretreatment of HepG2 cells with pulp or peel/seed hydroalcoholic extract significantly protected against the cytotoxicity induced by $\mathrm{CCl}_{4}$. Additionally, the cells treated with both extracts (both at $1000 \mu \mathrm{g} / \mathrm{mL}$ ) showed normal morphology (general and nuclear), in contrast to the apoptotic characteristics of the cells only exposed to $\mathrm{CCl}_{4}[172]$.

In another study, using a similar model, Abdou et al. [173] found that the administration of an ethanol extract of leaves from $S$. terebinthifolius significantly protected against $\mathrm{CCl}_{4}$ liver damage in Wistar rats. Interestingly, $S$. terebinthifolius extract inhibited hepatocyte apoptosis as revealed by an approximate 20-time downregulation in caspase-3 expression compared with the $\mathrm{CCl}_{4}$-untreated group. Endringer et al. [97] investigated the capacity of $H$. speciosa to induce antioxidant response element (ARE) activation in HepG2 cells transfected with ARE-luciferase plasmid. ARE is a regulatory enhancer gene encoding protective proteins, including phase II detoxification enzymes such as $\mathrm{NAD}(\mathrm{P}) \mathrm{H}$ :quinone oxidoreductase and antioxidant enzymes such as glutathione (GSH) S-transferases (GST). Extracts and fractions (methanol and methanol: water $(1: 1)$ ) caused ARE induction.

\section{Conclusion}

The evidence discussed in this review indicates that the medicinal plants from the Cerrado show antioxidant activity, anticancer activity, and protective effects against chemical toxicity. These plants are potential candidates for the identification of effective pharmacological compounds. Therefore, the in vivo assay followed by clinical trials may provide clear evidence on the potential benefits of these extracts and/or isolated compounds and may facilitate the development of alternative therapeutic strategies and the design and selection of new drugs for cancer therapy. 


\section{Conflicts of Interest}

The authors declare that they have no conflicts of interest.

\section{Acknowledgments}

This work was supported by grants from Universidade Federal da Grande Dourados (UFGD); Fundação de Apoio ao Desenvolvimento do Ensino, Ciência e Tecnologia do Estado de Mato Grosso do Sul (FUNDECT); Coordenação de Aperfeiçoamento de Pessoal de Nível Superior (CAPES); Conselho Nacional de Desenvolvimento Científico e Tecnológico $(\mathrm{CNPq})$; and Financiadora de Estudos e Projetos (FINEP).

\section{References}

[1] L. Katz and R. H. Baltz, "Natural product discovery: past, present, and future," Journal of Industrial Microbiology \& Biotechnology, vol. 43, no. 2-3, pp. 155-176, 2016.

[2] D. J. Newman and G. M. Cragg, "Natural products as sources of new drugs from 1981 to 2014," Journal of Natural Products, vol. 79, no. 3, pp. 629-661, 2016.

[3] S. Florian and T. J. Mitchison, "Anti-microtubule drugs," in Mitotic Spindle Methods Protoc, P. Chang and R. Ohi, Eds., pp. 403-421, Springer New York, New York, NY, 2016, cited 2019 Feb 28.

[4] D.-P. Xu, Y. Li, X. Meng et al., "Natural antioxidants in foods and medicinal plants: extraction, assessment and resources," International Journal of Molecular Sciences, vol. 18, no. 1, p. 96, 2017.

[5] N. Khansari, Y. Shakiba, and M. Mahmoudi, "Chronic inflammation and oxidative stress as a major cause of agerelated diseases and cancer," Recent Patents on Inflammation \& Allergy Drug Discovery, vol. 3, no. 1, pp. 73-80, 2009.

[6] A. Lichota and K. Gwozdzinski, "Anticancer activity of natural compounds from plant and marine environment," International Journal of Molecular Sciences, vol. 19, no. 11, p. 3533, 2018.

[7] S. Habtemariam and G. Lentini, "Plant-derived anticancer agents: lessons from the pharmacology of geniposide and its aglycone, genipin," Biomedicines, vol. 6, no. 2, p. 39, 2018.

[8] R. C. Dutra, M. M. Campos, A. R. S. Santos, and J. B. Calixto, "Medicinal plants in Brazil: pharmacological studies, drug discovery, challenges and perspectives," Pharmacological Research, vol. 112, pp. 4-29, 2016.

[9] M. Valli, H. M. Russo, and V. S. Bolzani, "The potential contribution of the natural products from Brazilian biodiversity to bioeconomy," Anais da Academia Brasileira de Ciências, vol. 90, 1 suppl 1, pp. 763-778, 2018.

[10] A. C. Pilon, M. Valli, A. C. Dametto et al., "NuBBEDB: an updated database to uncover chemical and biological information from Brazilian biodiversity," Scientific Reports, vol. 7, no. 1, p. 7215, 2017.

[11] C. J. R. Alho, "The value of biodiversity," Brazilian Journal of Biology, vol. 68, 4 suppl, pp. 1115-1118, 2008.

[12] E. E. Sano, A. A. Rodrigues, E. S. Martins et al., "Cerrado ecoregions: a spatial framework to assess and prioritize Brazilian savanna environmental diversity for conservation,"
Journal of Environmental Management, vol. 232, pp. 818$828,2019$.

[13] V. C. da Silva and C. M. Rodrigues, "Natural products: an extraordinary source of value-added compounds from diverse biomasses in Brazil," Chemical and Biological Technologies in Agriculture, vol. 1, no. 1, p. 14, 2014.

[14] D. C. Savi, R. Aluizio, and C. Glienke, "Brazilian plants: an unexplored source of endophytes as producers of active metabolites," Planta Medica, vol. 85, no. 08, pp. 619-636, 2019.

[15] G. Damasco, C. Fontes, R. Françoso, and R. Haidar, "The Cerrado biome: a forgotten biodiversity hotspot," Frontiers for Young Minds, vol. 6, 2018.

[16] D. Baldivia, D. Leite, D. Castro et al., "Evaluation of in vitro antioxidant and anticancer properties of the aqueous extract from the stem bark of Stryphnodendron adstringens," International Journal of Molecular Sciences, vol. 19, no. 8, p. 2432, 2018.

[17] J. F. Campos, P. P. T. Espindola, H. F. V. Torquato et al., "Leaf and root extracts from Campomanesia adamantium (Myrtaceae) promote apoptotic death of leukemic cells via activation of intracellular calcium and caspase-3," Frontiers in Pharmacology, vol. 8, p. 466, 2017.

[18] J. F. Campos, D. T. H. de Castro, M. J. Damião et al., "The Chemical Profile ofSenna velutinaLeaves and Their Antioxidant and Cytotoxic Effects," Oxidative Medicine and Cellular Longevity, vol. 2016, Article ID 8405957, 12 pages, 2016.

[19] J. C. Casagrande, L. F. B. Macorini, K. A. Antunes et al., "Antioxidant and cytotoxic activity of hydroethanolic extract from Jacaranda decurrens leaves," PLoS One, vol. 9, no. 11, 2014.

[20] U. P. Santos, J. F. Campos, H. F. V. Torquato et al., “Antioxidant, antimicrobial and cytotoxic properties as well as the phenolic content of the extract from Hancornia speciosa Gomes," PloS One, vol. 11, no. 12, 2016.

[21] P. dos Santos da Rocha, J. F. Campos, V. Nunes-Souza et al., "Antioxidant and protective effects of Schinus terebinthifolius Raddi against doxorubicin-induced toxicity," Applied Biochemistry and Biotechnology, vol. 184, no. 3, pp. 869-884, 2018.

[22] J. M. dos Santos, T. M. Alfredo, K. Á. Antunes et al., "Guazuma ulmifoliaLam. Decreases Oxidative Stress in Blood Cells and Prevents Doxorubicin-Induced Cardiotoxicity," Oxidative Medicine and Cellular Longevity, vol. 2018, Article ID 2935051, 16 pages, 2018.

[23] L. M. Ricardo, B. M. Dias, F. L. B. Mügge, V. V. Leite, and M. G. L. Brandão, "Evidence of traditionality of Brazilian medicinal plants: the case studies of Stryphnodendron adstringens (Mart.) Coville (barbatimão) barks and Copaifera spp. (copaíba) oleoresin in wound healing," Journal of Ethnopharmacology, vol. 219, pp. 319-336, 2018.

[24] S. C. Pinto, F. Bueno, G. Panizzon et al., "Stryphnodendron adstringens: clarifying wound healing in Streptozotocininduced diabetic rats," Planta Medica, vol. 81, no. 12/13, pp. 1090-1096, 2015.

[25] B. O. Henriques, O. Corrêa, E. P. C. Azevedo et al., "In vitro TNF- $\alpha$ inhibitory activity of Brazilian plants and antiinflammatory effect of Stryphnodendron adstringens in an acute arthritis model," Evidence-based Complementary and Alternative Medicine, vol. 2016, Article ID 9872598, 15 pages, 2016. 
[26] E. A. Audi, D. P. Toledo, P. G. Peres et al., "Gastric antiulcerogenic effects ofStryphnodendron adstringens in rats," Phytotherapy Research, vol. 13, no. 3, pp. 264-266, 1999.

[27] P. De Souza, P. de Sales, L. Simeoni, E. Silva, D. Silveira, and P. de Oliveira Magalhães, "Inhibitory Activity of $\alpha$ Amylase and $\alpha$-Glucosidase by Plant Extracts from the Brazilian Cerrado," Planta Medica, vol. 78, no. 04, pp. 393-399, 2012.

[28] K. Ishida, S. Rozental, J. C. de Mello, and C. V. Nakamura, "Activity of tannins from Stryphnodendron adstringens on Cryptococcus neoformans: effects on growth, capsule size and pigmentation," Annals of Clinical Microbiology and Antimicrobials, vol. 8, no. 1, p. 29, 2009.

[29] A. L. D. de Freitas, V. Kaplum, D. C. P. Rossi et al., "Proanthocyanidin polymeric tannins from Stryphnodendron adstringens are effective against Candida spp. isolates and for vaginal candidiasis treatment," Journal of Ethnopharmacology, vol. 216, pp. 184-190, 2018.

[30] K. Ishida, J. C. P. de Mello, D. A. G. Cortez, B. P. D. Filho, T. Ueda-Nakamura, and C. V. Nakamura, "Influence of tannins from Stryphnodendron adstringens on growth and virulence factors of Candida albicans," J Antimicrob Chemother, vol. 58, no. 5, pp. 942-949, 2006.

[31] A. M. M. Felipe, V. P. Rincão, F. J. Benati et al., “Antiviral effect of Guazuma ulmifolia and Stryphnodendron adstringens on poliovirus and bovine herpesvirus," Biological \& Pharmaceutical Bulletin, vol. 29, no. 6, pp. 1092-1095, 2006.

[32] E. M. Pereira, R. Gomes, N. Freire, E. Aguiar, M. Brandão, and V. Santos, "In vitroAntimicrobial Activity of Brazilian Medicinal Plant Extracts against Pathogenic Microorganisms of Interest to Dentistry," Planta Medica, vol. 77, no. 04, pp. 401-404, 2011.

[33] T. M. Souza-Moreira, G. M. Queiroz-Fernandes, and R. C. L. R. Pietro, "Stryphnodendron species known as "barbatimão": a comprehensive report," Molecules, vol. 23, no. 4, p. 910, 2018.

[34] C. H. Lescano, F. Freitas de Lima, C. B. Mendes-Silvério et al., "Effect of polyphenols from Campomanesia adamantium on platelet aggregation and inhibition of cyclooxygenases: molecular docking and in vitro analysis," Frontiers in Pharmacology, vol. 9, p. 617, 2018.

[35] D. Zuntini Viscardi, J. S. Arrigo, C. A. C. Correia et al., "Seed and peel essential oils obtained from Campomanesia adamantium fruit inhibit inflammatory and pain parameters in rodents," PloS One, vol. 12, no. 2, 2017.

[36] L. C. Ferreira, A. Grabe-Guimarães, C. A. de Paula et al., "Anti-inflammatory and antinociceptive activities of Campomanesia adamantium," Journal of Ethnopharmacology, vol. 145, no. 1, pp. 100-108, 2013.

[37] C. H. Lescano, I. P. de Oliveira, T. Zaminelli et al., "Campomanesia adamantium peel extract in antidiarrheal activity: the ability of inhibition of heat-stable enterotoxin by polyphenols," PloS One, vol. 11, no. 10, p. e0165208, 2016.

[38] P. P. de Toledo Espindola, P. dos Santos da Rocha, C. A. Carollo et al., "Antioxidant and Antihyperlipidemic Effects ofCampomanesia adamantiumO. Berg Root," Oxidative Medicine and Cellular Longevity, vol. 2016, Article ID 7910340, 8 pages, 2016.

[39] C. M. L. Cardozo, A. Inada, G. Marcelino et al., "Therapeutic potential of Brazilian Cerrado Campomanesia species on metabolic dysfunctions," Molecules, vol. 23, no. 9, p. 2336, 2018.
[40] T. de Mello Moraes, C. M. Rodrigues, H. Kushima et al., "Hancornia speciosa: indications of gastroprotective, healing and anti-Helicobacter pylori actions," Journal of Ethnopharmacology, vol. 120, no. 2, pp. 161-168, 2008.

[41] D. G. Marinho, D. S. Alviano, M. E. Matheus, C. S. Alviano, and P. D. Fernandes, "The latex obtained from Hancornia speciosa Gomes possesses anti-inflammatory activity," Journal of Ethnopharmacology, vol. 135, no. 2, pp. 530-537, 2011.

[42] G. C. Silva, F. C. Braga, M. P. Lima, J. L. Pesquero, V. S. Lemos, and S. F. Cortes, "Hancornia speciosa Gomes induces hypotensive effect through inhibition of ACE and increase on NO," Journal of Ethnopharmacology, vol. 137, no. 1, pp. 709713, 2011.

[43] H. C. Ferreira, C. P. Serra, D. C. Endringer, V. S. Lemos, F. C. Braga, and S. F. Cortes, "Endothelium-dependent vasodilation induced by Hancornia speciosa in rat superior mesenteric artery," Phytomedicine, vol. 14, no. 7-8, pp. 473-478, 2007.

[44] H. C. Ferreira, C. P. Serra, V. S. Lemos, F. C. Braga, and S. F. Cortes, "Nitric oxide-dependent vasodilatation by ethanolic extract of Hancornia speciosa via phosphatidyl-inositol 3-kinase," Journal of Ethnopharmacology, vol. 109, no. 1, pp. 161-164, 2007.

[45] A. C. Pereira, A. B. D. Pereira, C. C. L. Moreira et al., "Hancornia speciosa Gomes (Apocynaceae) as a potential anti-diabetic drug," Journal of Ethnopharmacology, vol. 161, pp. 30-35, 2015.

[46] U. P. Dos Santos, G. S. Tolentino, J. S. Morais, K. de Picoli Souza, L. M. Estevinho, and E. L. dos Santos, "Physicochemical Characterization, Microbiological Quality and Safety, and Pharmacological Potential ofHancornia speciosaGomes," Oxidative Medicine and Cellular Longevity, vol. 2018, Article ID 2976985, 17 pages, 2018.

[47] P. dos Santos da Rocha, A. P. de Araújo Boleti, M. do Carmo Vieira et al., "Microbiological quality, chemical profile as well as antioxidant and antidiabetic activities of Schinus terebinthifolius Raddi," Comparative Biochemistry and Physiology Part C: Toxicology \& Pharmacology, vol. 220, pp. 36-46, 2019.

[48] T. Scheid, M. S. Moraes, T. P. Henriques et al., "Effects of Methanol Fraction from Leaves ofSchinus terebinthifoliusRaddi on Nociception and Spinal-Cord Oxidative Biomarkers in Rats with Neuropathic Pain," Evidence-Based Complementary and Alternative Medicine, vol. 2018, Article ID 5783412, 11 pages, 2018.

[49] L. de Lima Glória, M. B. de Souza Arantes, S. M. de Faria Pereira et al., "Phenolic compounds present Schinus terebinthifolius Raddi influence the lowering of blood pressure in rats," Molecules, vol. 22, no. 10, p. 1792, 2017.

[50] E. C. Rosas, L. B. Correa, T. A. Pádua et al., "Anti-inflammatory effect of Schinus terebinthifolius Raddi hydroalcoholic extract on neutrophil migration in zymosan-induced arthritis," Journal of Ethnopharmacology, vol. 175, pp. 490-498, 2015.

[51] A. Ennigrou, H. Casabianca, E. Vulliet, B. Hanchi, and K. Hosni, "Assessing the fatty acid, essential oil composition, their radical scavenging and antibacterial activities of Schinus terebinthifolius Raddi leaves and twigs," Journal of Food Science and Technology, vol. 55, no. 4, pp. 1582-1590, 2018.

[52] L. R. M. Estevão, R. S. Simões, P. Cassini-Vieira et al., "Schinus terebinthifolius Raddi (Aroeira) leaves oil attenuates inflammatory responses in cutaneous wound healing in 
mice," Acta Cirúrgica Brasileira, vol. 32, no. 9, pp. 726-735, 2017.

[53] F. Tonial, B. H. L. N. S. Maia, J. A. Gomes-Figueiredo et al., "Influence of culturing conditions on bioprospecting and the antimicrobial potential of endophytic fungi from Schinus terebinthifolius," Current Microbiology, vol. 72, no. 2, pp. 173-183, 2016.

[54] S. R. Nocchi, G. F. de Moura-Costa, C. R. Novello et al., "In vitro cytotoxicity and anti-herpes simplex virus type 1 activity of hydroethanolic extract, fractions, and isolated compounds from stem bark of Schinus terebinthifolius Raddi," Pharmacognosy Magazine, vol. 12, no. 46, pp. 160-164, 2016.

[55] K. Torres, S. Lima, and S. Ueda, "Activity of the aqueous extract of Schinus terebinthifolius Raddi on strains of the Candida genus," Revista Brasileira de Ginecologia e Obstetrícia / RBGO Gynecology and Obstetrics, vol. 38, no. 12, pp. 593-599, 2016.

[56] J. H. S. da Silva, N. K. Simas, C. S. Alviano et al., "AntiEscherichia coli activity of extracts from Schinus terebinthifolius fruits and leaves," Natural Product Research, vol. 32, no. 11, pp. 1365-1368, 2018.

[57] D. M. Pilatti, A. M. T. Fortes, T. C. M. Jorge, and N. P. Boiago, "Comparison of the phytochemical profiles of five native plant species in two different forest formations," Brazilian Journal of Biology, vol. 79, no. 2, pp. 233-242, 2019.

[58] K. A. Antunes, D. S. Baldivia, P. S. da Rocha et al., "Antiobesity Effects of Hydroethanolic Extract ofJacaranda decurrensLeaves," Evidence-Based Complementary and Alternative Medicine, vol. 2016, Article ID 4353604, 8 pages, 2016.

[59] J. A. Santos, A. Arruda, M. A. Silva et al., “Anti-inflammatory effects and acute toxicity of hydroethanolic extract of Jacaranda decurrens roots in adult male rats," Journal of Ethnopharmacology, vol. 144, no. 3, pp. 802-805, 2012.

[60] R. U. Y. J. V. ALVES, N. L. B. E. R. G. DA SILVA, A. L. U. S. I. O. J. FERNANDES JUNIOR, and A. L. E. S. S. A. N. D. R. A. R. GUIMARAES, "Longevity of the Brazilian underground tree Jacaranda decurrens Cham," Anais da Academia Brasileira de Ciências, vol. 85, no. 2, pp. 671-678, 2013.

[61] A. J. Alonso-Castro and L. A. Salazar-Olivo, "The antidiabetic properties of Guazuma ulmifolia Lam are mediated by the stimulation of glucose uptake in normal and diabetic adipocytes without inducing adipogenesis," Journal of Ethnopharmacology, vol. 118, no. 2, pp. 252-256, 2008.

[62] C. Caballero-George, P. M. Vanderheyden, T. de Bruyne et al., "In VitroInhibition of [3H]-Angiotensin II Binding on the Human AT1Receptor by Proanthocyanidins fromGuazuma ulmifoliaBark," Planta Medica, vol. 68, no. 12, pp. 1066-1071, 2002.

[63] B. Berenguer, C. Trabadela, S. Sánchez-Fidalgo et al., “The aerial parts of Guazuma ulmifolia Lam. protect against NSAID-induced gastric lesions," Journal of Ethnopharmacology, vol. 114, no. 2, pp. 153-160, 2007.

[64] M. Hör, H. Rimpler, and M. Heinrich, "Inhibition of Intestinal Chloride Secretion by Proanthocyanidins fromGuazuma ulmifolia," Planta Medica, vol. 61, no. 03, pp. 208-212, 1995.

[65] H. R. A. Pires, A. C. Franco, M. T. F. Piedade, V. V. Scudeller, B. Kruijt, and C. S. Ferreira, "Flood tolerance in two tree species that inhabit both the Amazonian floodplain and the dry Cerrado savanna of Brazil," AoB PLANTS, vol. 10, 2018.
[66] M. Valko, D. Leibfritz, J. Moncol, M. T. D. Cronin, M. Mazur, and J. Telser, "Free radicals and antioxidants in normal physiological functions and human disease," The International Journal of Biochemistry \& Cell Biology, vol. 39, no. 1, pp. 44-84, 2007.

[67] A. Chandrasekaran, M. P. S. Idelchik, and J. A. Melendez, "Redox control of senescence and age-related disease," Redox Biology, vol. 11, pp. 91-102, 2017.

[68] P. Poprac, K. Jomova, M. Simunkova, V. Kollar, C. J. Rhodes, and M. Valko, "Targeting free radicals in oxidative stressrelated human diseases," Trends in Pharmacological Sciences, vol. 38, no. 7, pp. 592-607, 2017.

[69] O. Firuzi, R. Miri, M. Tavakkoli, and L. Saso, "Antioxidant therapy: current status and future prospects," Current Medicinal Chemistry, vol. 18, no. 25, pp. 3871-3888, 2011.

[70] A. Srivastava and A. Srivastava, "Oxidative stress-mediated human diseases," in Oxidative Stress: Diagnostic Methods and Applications in Medical Science, P. K. Maurya and P. Chandra, Eds., Springer, Singapore, 2017.

[71] M. A. Babizhayev, "Mitochondria induce oxidative stress, generation of reactive oxygen species and redox state unbalance of the eye lens leading to human cataract formation: disruption of redox lens organization by phospholipid hydroperoxides as a common basis for cataract disease," Cell Biochemistry and Function, vol. 29, no. 3, pp. 183-206, 2011.

[72] M. Redza-Dutordoir and D. A. Averill-Bates, "Activation of apoptosis signalling pathways by reactive oxygen species," Biochimica et Biophysica Acta (BBA) - Molecular Cell Research, vol. 1863, no. 12, pp. 2977-2992, 2016.

[73] E. Birben, U. M. Sahiner, C. Sackesen, S. Erzurum, and O. Kalayci, "Oxidative stress and antioxidant defense," World Allergy Organization Journal, vol. 5, no. 1, pp. 9-19, 2012.

[74] V. Lubrano and S. Balzan, "Enzymatic antioxidant system in vascular inflammation and coronary artery disease," World Journal of Experimental Medicine, vol. 5, no. 4, pp. 218-224, 2015.

[75] M. Daglia, A. Di Lorenzo, S. F. Nabavi, Z. S. Talas, and S. M. Nabavi, "Polyphenols: well beyond the antioxidant capacity: gallic acid and related compounds as neuroprotective agents: you are what you eat!," Current Pharmaceutical Biotechnology, vol. 15, no. 4, pp. 362-372, 2014.

[76] C. G. Fraga, K. D. Croft, D. O. Kennedy, and F. A. TomásBarberán, "The effects of polyphenols and other bioactives on human health," Food \& Function, vol. 10, no. 2, pp. 514-528, 2019.

[77] M. Suwalsky, J. Colina, M. J. Gallardo et al., "Antioxidant capacity of gallic acid in vitro assayed on human erythrocytes," The Journal of Membrane Biology, vol. 249, no. 6, pp. 769-779, 2016.

[78] S. Choubey, S. Goyal, L. R. Varughese, V. Kumar, A. K. Sharma, and V. Beniwal, "Probing gallic acid for its broad spectrum applications," Mini Reviews in Medicinal Chemistry, vol. 18, no. 15, pp. 1283-1293, 2018.

[79] S. Choubey, L. R. Varughese, V. Kumar, and V. Beniwal, "Medicinal importance of gallic acid and its ester derivatives: a patent review," Pharmaceutical Patent Analyst, vol. 4, no. 4, pp. 305-315, 2015.

[80] S. Li, M. Xu, Q. Niu et al., "Efficacy of procyanidins against in vivo cellular oxidative damage: a systematic review and meta-analysis," PLoS One, vol. 10, no. 10, article e0139455, 2015. 
[81] Q. Y. Zhu, D. D. Schramm, H. B. Gross et al., "Influence of cocoa flavanols and procyanidins on free radical-induced human erythrocyte hemolysis," Clinical \& Developmental Immunology, vol. 12, no. 1, pp. 27-34, 2005.

[82] M. Grzesik, K. Naparło, G. Bartosz, and I. Sadowska-Bartosz, "Antioxidant properties of catechins: comparison with other antioxidants," Food Chemistry, vol. 241, pp. 480-492, 2018.

[83] J. V. Higdon and B. Frei, "Tea catechins and polyphenols: health effects, metabolism, and antioxidant functions," Critical Reviews in Food Science and Nutrition, vol. 43, no. 1, pp. 89-143, 2003.

[84] S. P. Boyle, V. L. Dobson, S. J. Duthie, D. C. Hinselwood, J. A. Kyle, and A. R. Collins, "Bioavailability and efficiency of rutin as an antioxidant: a human supplementation study," European Journal of Clinical Nutrition, vol. 54, no. 10, pp. 774-782, 2000.

[85] S. Habtemariam, "Antioxidant and rutin content analysis of leaves of the common buckwheat (Fagopyrum esculentum Moench) grown in the United Kingdom: a case study," Antioxidants, vol. 8, no. 6, p. 160, 2019.

[86] A review of quercetin: chemistry, antioxidant properties, and bioavailabilityAvaliable from: https://www.jyi.org/.

[87] M. Zhang, S. G. Swarts, L. Yin et al., "Antioxidant properties of quercetin," Advances in Experimental Medicine and Biology, vol. 701, pp. 283-289, 2011.

[88] G. Barrera, "Oxidative stress and lipid peroxidation products in cancer progression and therapy," ISRN Oncology, vol. 2012, Article ID 137289, 21 pages, 2012.

[89] T. Brodniewicz and G. Grynkiewicz, "Preclinical drug development," Acta Poloniae Pharmaceutica, vol. 67, pp. 578-585, 2010.

[90] M. R. Fielden and K. L. Kolaja, "The role of early in vivo toxicity testing in drug discovery toxicology," Expert Opinion on Drug Safety, vol. 7, no. 2, pp. 107-110, 2008.

[91] K. Pavithra and S. Vadivukkarasi, "Evaluation of free radical scavenging activity of various extracts of leaves from Kedrostis foetidissima (Jacq.) Cogn," Food Science and Human Wellness, vol. 4, no. 1, pp. 42-46, 2015.

[92] F. Bray, J. Ferlay, I. Soerjomataram, R. L. Siegel, L. A. Torre, and A. Jemal, "Global cancer statistics 2018: GLOBOCAN estimates of incidence and mortality worldwide for 36 cancers in 185 countries," CA: a Cancer Journal for Clinicians, vol. 68, no. 6, pp. 394-424, 2018.

[93] G. E. Forcados, D. B. James, A. B. Sallau, A. Muhammad, and P. Mabeta, "Oxidative stress and carcinogenesis: potential of phytochemicals in breast cancer therapy," Nutrition and Cancer, vol. 69, no. 3, pp. 365-374, 2017.

[94] J. E. Klaunig and Z. Wang, "Oxidative stress in carcinogenesis," Current Opinion in Toxicology, vol. 7, pp. 116-121, 2018.

[95] A. Nagarajan, P. Malvi, and N. Wajapeyee, "Oncogenedirected alterations in cancer cell metabolism," Trends in Cancer, vol. 2, no. 7, pp. 365-377, 2016.

[96] T. Fatemian and E. Chowdhury, "Targeting oncogenes and tumor suppressors genes to mitigate chemoresistance," Current Cancer Drug Targets, vol. 14, no. 7, pp. 599-609, 2014.

[97] D. C. Endringer, Y. M. Valadares, P. R. V. Campana et al., "Evaluation of Brazilian plants on cancer chemoprevention targetsin vitro," Phytotherapy Research, vol. 24, no. 6, pp. n/a-n33, 2009.
[98] Y. J. Surh, "NF- $\kappa$ B and Nrf2 as potential chemopreventive targets of some anti-inflammatory and antioxidative phytonutrients with anti-inflammatory and antioxidative activities," Asia Pacific Journal of Clinical Nutrition, vol. 17, no. S1, pp. 269-272, 2008.

[99] S. Nair, W. Li, and A.-N. T. Kong, "Natural dietary anticancer chemopreventive compounds: redox-mediated differential signaling mechanisms in cytoprotection of normal cells versus cytotoxicity in tumor cells," Acta Pharmacologica Sinica, vol. 28, no. 4, pp. 459-472, 2007.

[100] D. Delmas and J. Xiao, "EDITORIAL (Hot Topic: Natural Polyphenols Properties: Chemopreventive and Chemosensitizing Activities)," Anti-Cancer Agents in Medicinal Chemistry, vol. 12, no. 8, p. 835, 2012.

[101] F. Ghiringhelli, C. Rebe, A. Hichami, and D. Delmas, "Immunomodulation and anti-inflammatory roles of polyphenols as anticancer agents," Anti-Cancer Agents in Medicinal Chemistry, vol. 12, no. 8, pp. 852-873, 2012.

[102] M. Greenwell and P. K. S. M. Rahman, "Medicinal plants: their use in anticancer treatment," International Journal of Pharmaceutical Sciences and Research, vol. 6, no. 10, pp. 4103-4112, 2015.

[103] A. M. L. Seca and D. C. G. A. Pinto, "Plant secondary metabolites as anticancer agents: successes in clinical trials and therapeutic application," International Journal of Molecular Sciences, vol. 19, no. 1, p. 263, 2018.

[104] R. C. Taylor, S. P. Cullen, and S. J. Martin, “Apoptosis: controlled demolition at the cellular level," Nature Reviews. Molecular Cell Biology, vol. 9, no. 3, pp. 231-241, 2008.

[105] G. Ichim and S. W. G. Tait, "A fate worse than death: apoptosis as an oncogenic process," Nature Reviews. Cancer, vol. 16, no. 8, pp. 539-548, 2016.

[106] D. Hanahan and R. A. Weinberg, "The hallmarks of cancer," Cell, vol. 100, no. 1, pp. 57-70, 2000.

[107] R. E. Martell, D. Sermer, K. Getz, and K. I. Kaitin, “Oncology drug development and approval of systemic anticancer therapy by the U.S. Food and Drug Administration," The Oncologist, vol. 18, no. 1, pp. 104-111, 2013.

[108] J. Sun, Q. Wei, Y. Zhou, J. Wang, Q. Liu, and H. Xu, “A systematic analysis of FDA-approved anticancer drugs," BMC Systems Biology, vol. 11, Suppl 5, p. 87, 2017.

[109] C. Pfeffer and A. Singh, "Apoptosis: a target for anticancer therapy," International Journal of Molecular Sciences, vol. 19, no. 2, p. 448, 2018.

[110] H. Gali-Muhtasib, R. Hmadi, M. Kareh, R. Tohme, and N. Darwiche, "Cell death mechanisms of plant-derived anticancer drugs: beyond apoptosis," Apoptosis, vol. 20, no. 12, pp. 1531-1562, 2015.

[111] Q. Chen, J. Kang, and C. Fu, "The independence of and associations among apoptosis, autophagy, and necrosis," Signal Transduction and Targeted Therapy, vol. 3, no. 1, p. 18, 2018.

[112] S. Elmore, "Apoptosis: a review of programmed cell death," Toxicologic Pathology, vol. 35, no. 4, pp. 495-516, 2007.

[113] C. Feig and M. . E. Peter, "How apoptosis got the immune system in shape," European Journal of Immunology, vol. 37, Suppl 1, pp. S61-S70, 2007.

[114] J. T. Opferman, "Apoptosis in the development of the immune system," Cell Death and Differentiation, vol. 15, no. 2, pp. 234-242, 2008.

[115] S. Baig, I. Seevasant, J. Mohamad, A. Mukheem, H. Z. Huri, and T. Kamarul, "Potential of apoptotic pathway-targeted 
cancer therapeutic research: where do we stand?," Cell Death \& Disease, vol. 7, article e2058, 2016.

[116] J. Berthelet and L. Dubrez, "Regulation of apoptosis by inhibitors of apoptosis (IAPs)," Cell, vol. 2, no. 1, pp. 163-187, 2013.

[117] J. Silke and D. Vucic, "IAP family of cell death and signaling regulators," Methods in Enzymology, vol. 545, pp. 35-65, 2014.

[118] D. Vasudevan and H. D. Ryoo, "Regulation of cell death by IAPs and their antagonists," Current Topics in Developmental Biology, vol. 114, pp. 185-208, 2015.

[119] W.-T. Chiu, H. A. Chang, Y. H. Lin et al., "Bcl-2 regulates store-operated $\mathrm{Ca}^{2+}$ entry to modulate ER stress-induced apoptosis," Cell Death Discovery, vol. 4, no. 1, 2018.

[120] B. Zhivotovsky and S. Orrenius, "Calcium and cell death mechanisms: a perspective from the cell death community," Cell Calcium, vol. 50, no. 3, pp. 211-221, 2011.

[121] S. Orrenius, V. Gogvadze, and B. Zhivotovsky, "Calcium and mitochondria in the regulation of cell death," Biochemical and Biophysical Research Communications, vol. 460, no. 1, pp. 72-81, 2015.

[122] S. W. G. Tait and D. R. Green, "Mitochondria and cell death: outer membrane permeabilization and beyond," Nature Reviews. Molecular Cell Biology, vol. 11, no. 9, pp. 621-632, 2010.

[123] L. Galluzzi, O. Kepp, and G. Kroemer, "Mitochondrial regulation of cell death: a phylogenetically conserved control," Microbial Cell, vol. 3, no. 3, pp. 101-108, 2016.

[124] P. E. Czabotar, G. Lessene, A. Strasser, and J. M. Adams, "Control of apoptosis by the BCL-2 protein family: implications for physiology and therapy," Nature Reviews. Molecular Cell Biology, vol. 15, no. 1, pp. 49-63, 2014.

[125] H. M. Heath-Engel, N. C. Chang, and G. C. Shore, "The endoplasmic reticulum in apoptosis and autophagy: role of the BCL-2 protein family," Oncogene, vol. 27, no. 50, pp. 6419-6433, 2008.

[126] S. J. Martin and C. M. Henry, "Distinguishing between apoptosis, necrosis, necroptosis and other cell death modalities," Methods, vol. 61, no. 2, pp. 87-89, 2013.

[127] E. Bobrovnikova-Marjon and J. B. Hurov, "Targeting metabolic changes in cancer: novel therapeutic approaches," Annual Review of Medicine, vol. 65, no. 1, pp. 157-170, 2014.

[128] C. Liu, K. Zhang, H. Shen, X. Yao, Q. Sun, and G. Chen, "Necroptosis: a novel manner of cell death, associated with stroke (review)," International Journal of Molecular Medicine, vol. 41, no. 2, pp. 624-630, 2018.

[129] A. Najafov, H. Chen, and J. Yuan, "Necroptosis and cancer," Trends Cancer., vol. 3, no. 4, pp. 294-301, 2017.

[130] P. Vandenabeele, L. Galluzzi, T. Vanden Berghe, and G. Kroemer, "Molecular mechanisms of necroptosis: an ordered cellular explosion," Nature Reviews. Molecular Cell Biology, vol. 11, no. 10, pp. 700-714, 2010.

[131] D. E. Christofferson and J. Yuan, "Necroptosis as an alternative form of programmed cell death," Current Opinion in Cell Biology, vol. 22, no. 2, pp. 263-268, 2010.

[132] X. Yu, Q. Deng, W. Li et al., "Neoalbaconol induces cell death through necroptosis by regulating RIPK-dependent autocrine TNF $\alpha$ and ROS production," Oncotarget, vol. 6, no. 4, pp. 1995-2008, 2015.

[133] W. Sun, X. Wu, H. Gao et al., "Cytosolic calcium mediates RIP1/RIP3 complex-dependent necroptosis through JNK activation and mitochondrial ROS production in human colon cancer cells," Free Radical Biology \& Medicine, vol. 108, pp. 433-444, 2017.

[134] N. Lalaoui and G. Brumatti, "Relevance of necroptosis in cancer," Immunology and Cell Biology, vol. 95, no. 2, pp. 137-145, 2017.

[135] A. Serrano-Puebla and P. Boya, "Lysosomal membrane permeabilization as a cell death mechanism in cancer cells," Biochemical Society Transactions, vol. 46, no. 2, pp. 207-215, 2018.

[136] A.-C. Johansson, H. Appelqvist, C. Nilsson, K. Kågedal, K. Roberg, and K. Öllinger, "Regulation of apoptosisassociated lysosomal membrane permeabilization," Apoptosis, vol. 15, no. 5, pp. 527-540, 2010.

[137] F. Wang, A. Salvati, and P. Boya, "Lysosome-dependent cell death and deregulated autophagy induced by aminemodified polystyrene nanoparticles," Open Biology, vol. 8, no. 4, p. 170271, 2018.

[138] F. Wang, R. Gómez-Sintes, and P. Boya, "Lysosomal membrane permeabilization and cell death," Traffic, vol. 19, no. 12, pp. 918-931, 2018.

[139] A. B. Pupyshev, "Lysosomal membrane permeabilization as apoptogenic factor," Tsitologiia, vol. 53, no. 4, pp. 313-324, 2011.

[140] S. Kaushik and A. M. Cuervo, "The coming of age of chaperone-mediated autophagy," Nature Reviews Molecular Cell Biology, vol. 19, no. 6, pp. 365-381, 2018.

[141] I. Dikic and Z. Elazar, "Mechanism and medical implications of mammalian autophagy," Nature Reviews. Molecular Cell Biology, vol. 19, no. 6, pp. 349-364, 2018.

[142] D. T. H. Castro, J. F. Campos, M. J. Damião et al., “Ethanolic Extract ofSenna velutinaRoots: Chemical Composition,In VitroandIn VivoAntitumor Effects, and B16F10-Nex2 Melanoma Cell Death Mechanisms," Oxidative Medicine and Cellular Longevity, vol. 2019, Article ID 5719483, 14 pages, 2019.

[143] M. C. B. Lima e Silva, D. Bogo, C. A. F. Alexandrino et al., "Antiproliferative activity of extracts ofCampomanesia adamantium(Cambess.) O. Berg and isolated compound dimethylchalcone against B16-F10 murine melanoma," Journal of Medicinal Food, vol. 21, no. 10, pp. 1024-1034, 2018.

[144] A. C. R. F. Pascoal, C. A. Ehrenfried, B. G. C. Lopez et al., "Antiproliferative activity and induction of apoptosis in PC-3 cells by the chalcone cardamonin from Campomanesia adamantium (Myrtaceae) in a bioactivity-guided study," Molecules, vol. 19, no. 2, pp. 1843-1855, 2014.

[145] C. C. F. Alves, J. D. Oliveira, E. B. B. Estevam et al., “Antiproliferative activity of essential oils from three plants of the Brazilian Cerrado: Campomanesia adamantium (Myrtaceae), Protium ovatum (Burseraceae) and Cardiopetalum calophyllum (Annonaceae)," Brazilian Journal of Biology, 2019.

[146] V. Kaplum, A. C. Ramos, M. E. L. Consolaro et al., "Proanthocyanidin polymer-rich fraction of Stryphnodendron adstringens promotes in vitro and in vivo cancer cell death via oxidative stress," Frontiers in Pharmacology, vol. 9, p. 694, 2018.

[147] A. P. L. Sabino, L. M. S. Eustáquio, A. C. F. Miranda, C. Biojone, T. N. Mariosa, and C. M. C. P. Gouvêa, "Stryphnodendron adstringens ("barbatimão") leaf fraction: chemical characterization, antioxidant activity, and cytotoxicity towards human breast cancer cell lines," Applied 
Biochemistry and Biotechnology, vol. 184, no. 4, pp. 13751389, 2018.

[148] F. Kroschinsky, F. Stölzel, S. von Bonin et al., "New drugs, new toxicities: severe side effects of modern targeted and immunotherapy of cancer and their management," Critical Care, vol. 21, no. 1, p. 89, 2017.

[149] X. Yu, Q. Deng, A. M. Bode, Z. Dong, and Y. Cao, "The role of necroptosis, an alternative form of cell death, in cancer therapy," Expert Review of Anticancer Therapy, vol. 13, no. 7, pp. 883-893, 2013.

[150] D. Chen, J. Yu, and L. Zhang, "Necroptosis: an alternative cell death program defending against cancer," Biochimica et Biophysica Acta (BBA) - Reviews on Cancer, vol. 1865, no. 2, pp. 228-236, 2016.

[151] P. G. Anantharaju, P. C. Gowda, M. G. Vimalambike, and S. R. V. Madhunapantula, "An overview on the role of dietary phenolics for the treatment of cancers," Nutrition Journal, vol. 15, no. 1, p. 99, 2016.

[152] L. F. Călinoiu and D. C. Vodnar, "Whole grains and phenolic acids: a review on bioactivity, functionality, health benefits and bioavailability," Nutrients, vol. 10, no. 11, article 1615, 2018 .

[153] T. Costea, A. Hudiță, O. A. Ciolac et al., "Chemoprevention of colorectal cancer by dietary compounds," International Journal of Molecular Sciences, vol. 19, no. 12, article 3787, 2018.

[154] K. W. J. Wahle, I. Brown, D. Rotondo, and S. D. Heys, "Plant phenolics in the prevention and treatment of cancer," Advances in Experimental Medicine and Biology, vol. 698, pp. 36-51, 2010.

[155] C. Kandaswami, L. T. Lee, P. P. Lee et al., "The antitumor activities of flavonoids," In Vivo, vol. 19, no. 5, pp. 895-909, 2005.

[156] A. Taleghani and Z. Tayarani-Najaran, "Potent cytotoxic natural flavonoids: the limits of perspective," Current Pharmaceutical Design, vol. 24, no. 46, pp. 5555-5579, 2019.

[157] F. N. Iheagwam, O. O. Ogunlana, O. E. Ogunlana, I. Isewon, and J. Oyelade, "Potential anti-cancer flavonoids isolated from Caesalpinia bonduc young twigs and leaves: molecular docking and in silico studies," Bioinformatics and Biology Insights, vol. 13, 2019.

[158] H. Zhang, X. Wu, J. Wang et al., "Flavonoids from the leaves of Epimedium Koreanum Nakai and their potential cytotoxic activities," Natural Product Research, vol. 19, pp. 1-8, 2019.

[159] F. B. Carneiro, P. Q. Lopes, R. C. Ramalho, M. T. Scotti, S. G. Santos, and L. A. L. Soares, "Characterization of leaf extracts of Schinus terebinthifolius Raddi by GC-MS and chemometric analysis," Pharmacognosy Magazine, vol. 13, no. 51, pp. 672-675, 2017.

[160] V. Fuchs-Tarlovsky, "Role of antioxidants in cancer therapy," Nutrition, vol. 29, no. 1, pp. 15-21, 2013.

[161] A. Thyagarajan and R. P. Sahu, "Potential contributions of antioxidants to cancer therapy: immunomodulation and radiosensitization," Integrative Cancer Therapies, vol. 17, no. 2, pp. 210-216, 2018.

[162] J. N. Moloney and T. G. Cotter, "ROS signalling in the biology of cancer," Seminars in Cell \& Developmental Biology, vol. 80, pp. 50-64, 2018.

[163] C. Gorrini, I. S. Harris, and T. W. Mak, "Modulation of oxidative stress as an anticancer strategy," Nature Reviews Drug Discovery, vol. 12, no. 12, pp. 931-947, 2013.
[164] J. Fang, T. Seki, and H. Maeda, "Therapeutic strategies by modulating oxygen stress in cancer and inflammation," Advanced Drug Delivery Reviews, vol. 61, no. 4, pp. 290302, 2009.

[165] A. Glasauer and N. S. Chandel, "Targeting antioxidants for cancer therapy," Biochemical Pharmacology, vol. 92, no. 1, pp. 90-101, 2014.

[166] S. Saeidnia and M. Abdollahi, "Antioxidants: friends or foe in prevention or treatment of cancer: the debate of the century," Toxicology and Applied Pharmacology, vol. 271, no. 1, pp. 4963, 2013

[167] J. Watson, "Oxidants, antioxidants and the current incurability of metastatic cancers," Open Biology, vol. 3, no. 1, article 120144, 2013.

[168] H. Yang, R. M. Villani, H. Wang et al., "The role of cellular reactive oxygen species in cancer chemotherapy," Journal of Experimental \& Clinical Cancer Research, vol. 37, no. 1, article 266, 2018.

[169] A. J. Montero and J. Jassem, "Cellular redox pathways as a therapeutic target in the treatment of cancer," Drugs, vol. 71, no. 11, pp. 1385-1396, 2011.

[170] J. Fang, H. Nakamura, and A. K. Iyer, "Tumor-targeted induction of oxystress for cancer therapy," Journal of Drug Targeting, vol. 15, no. 7-8, pp. 475-486, 2007.

[171] M. D. Martello, N. David, R. Matuo et al., "Campomanesia adamantium extract induces DNA damage, apoptosis, and affects cyclophosphamide metabolism," Genetics and Molecular Research, vol. 15, no. 2, 2016.

[172] T. de Oliveira Fernandes, R. I. de Ávila, S. S. de Moura, G. de Almeida Ribeiro, M. M. V. Naves, and M. C. Valadares, "Campomanesia adamantium (Myrtaceae) fruits protect HEPG2 cells against carbon tetrachloride-induced toxicity," Toxicology Reports, vol. 2, pp. 184-193, 2015.

[173] R. H. Abdou, S. Y. Saleh, and W. F. Khalil, “Toxicological and biochemical studies on Schinus terebinthifolius concerning its curative and hepatoprotective effects against carbon tetrachloride-induced liver injury," Pharmacognosy Magazine, vol. 11, Suppl 1, pp. S93-101, 2015. 


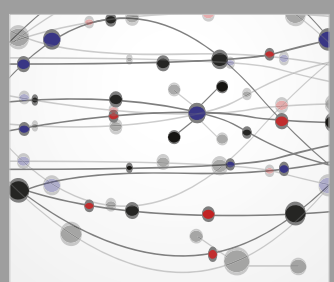

The Scientific World Journal
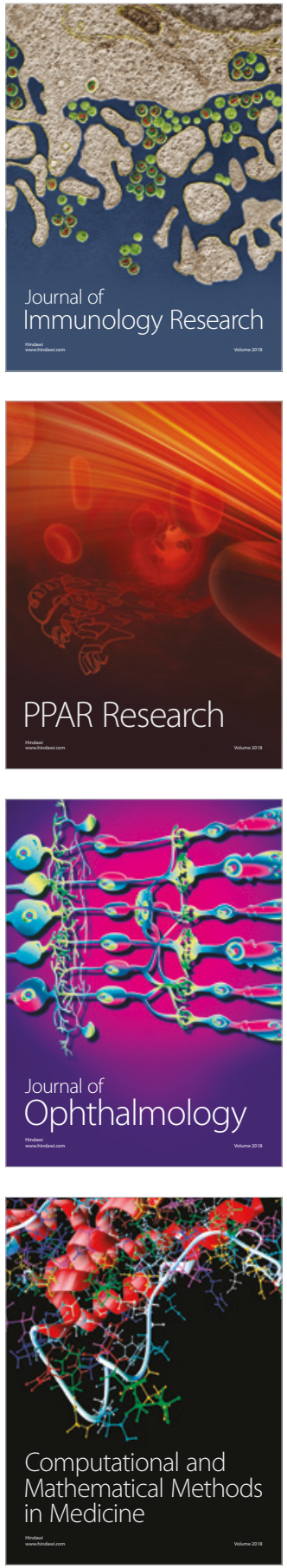

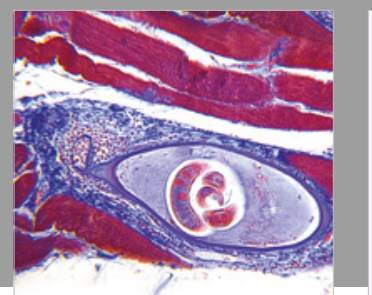

Gastroenterology Research and Practice

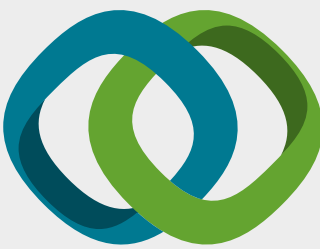

\section{Hindawi}

Submit your manuscripts at

www.hindawi.com
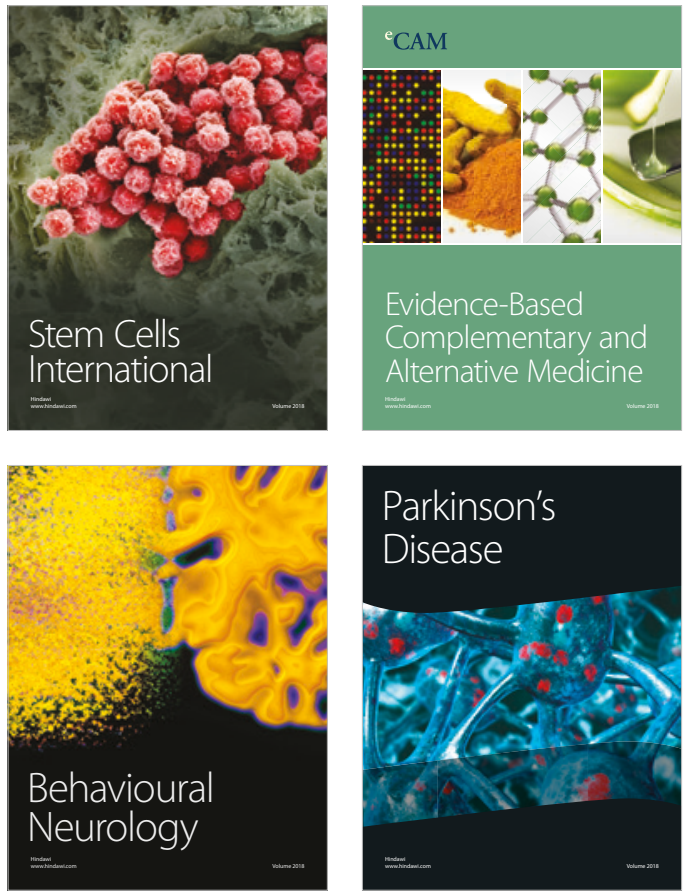

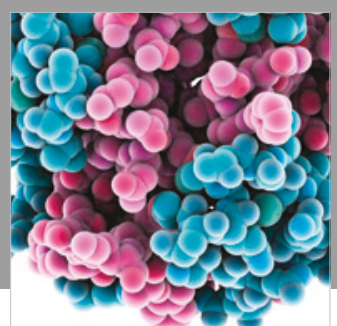

ournal of

Diabetes Research

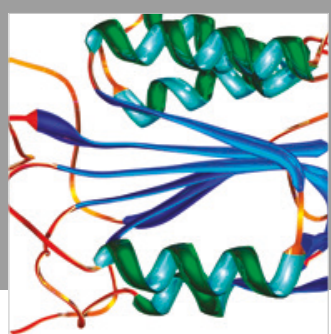

Disease Markers
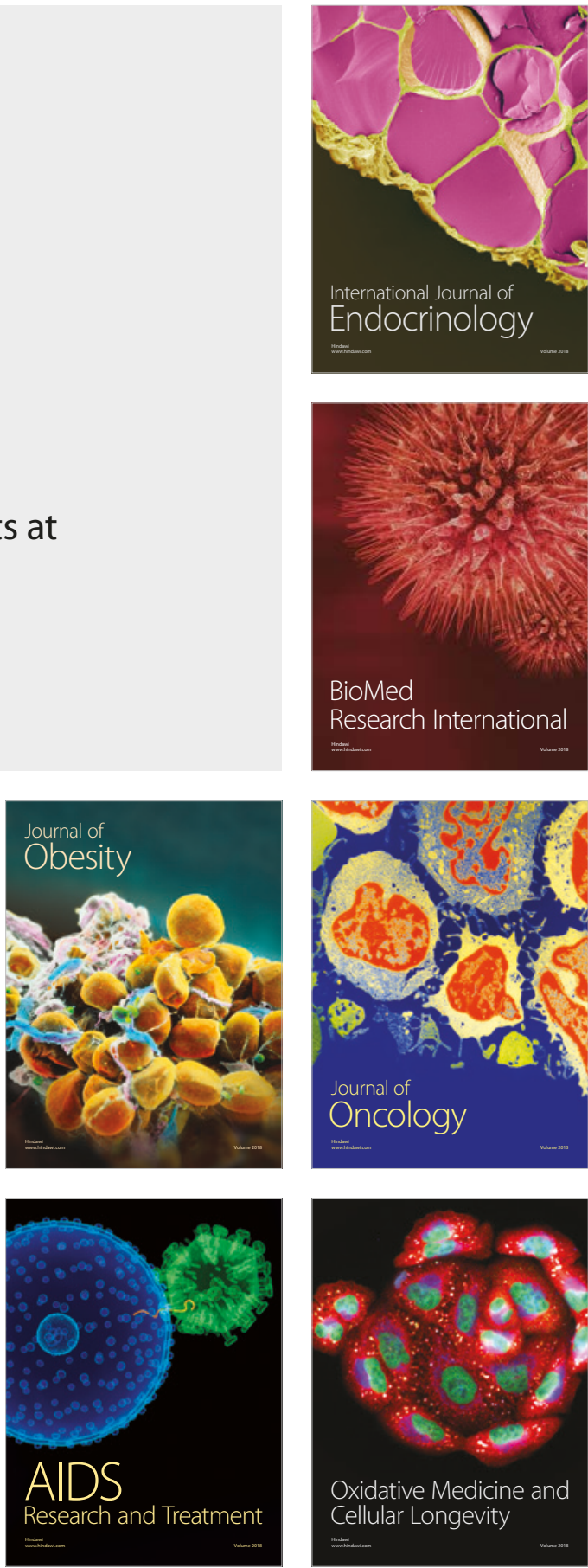